\title{
Da justificação e a fé como evento escatológico enquanto obediência e decisão fundada no ato da Graça de Deus segundo a Teologia do apóstolo Paulo em Rudolf Bultmann
}

\author{
Of justification and faith as an escatological event \\ while obedience and decision founded in the \\ act of the God's Grace according to the Theology \\ of the apostle Paul in Rudolf Bultmann
}

\section{*Luiz Carlos Mariano Da Rosa}

\section{Resumo}

Baseado no pensamento teológico de Bultmann e na sua hermenêutica existencialista, o artigo se detém na justificação e na sua relação com a fé como evento escatológico enquanto obediência e decisão fundada no ato da graça de Deus segundo a teologia do Apóstolo Paulo. Dessa forma, o artigo assinala que, consistindo a justiça de Deus em uma possibilidade para os ouvintes da pregação diante do caráter absoluto do domínio exercido pelo poder do pecado em um processo que subjuga todos os seres humanos à escravidão e implica a impossibilidade de justificação diante de Deus por intermédio das obras da Lei, a fé enquanto obediência e decisão constitui o evento escatológico em uma construção que a encerra como o novo caminho salvífico que, emergindo como a lei da fé, se contrapõe à lei das obras, convergindo para a justificação enquanto justiça de Deus. Assim, se a fé é uma concessão de Deus em um movimento que encerra a ideia de predestinação, tal caraterização não implica, contudo, uma operação que dispense o ser humano da responsabilidade do

"Doutorando em Filosofia pela Selinus University of Science and Literature (UNISELINOS - Londres / Inglaterra). Professor-Pesquisador e Filósofo-Educador na ONG Espaço Politikón Zôon (EPZ - São Paulo).Contato: marianodarosaletras@gmail.com 
ato de decisão, mas consiste no fato de que a referida possibilidade mantém dependência absoluta da graça de Deus e, dessa forma, constitui um evento no qual a decisão não pode emergir senão como dádiva de Deus.

Palavras-chave: Rudolf Bultmann; Apóstolo Paulo; fé; justificação; graça de Deus

\section{Abstract}

Based on Bultmann's theological thinking and his existentialist hermeneutics, the article focuses on justification and its relation with faith as an eschatological event as obedience and decision founded on the act of the God's grace according to the theology of the Apostle Paul. Thus, the article points out that, consisting of the God's justice in a possibility for the listeners of the preaching before the absolute character of the dominion exercised by the power of sin in a process that subjugates all human beings to slavery and implies the impossibility of justification before of God through the works of the Law, faith as obedience and decision constitutes the eschatological event in a construction that encloses it as the new salvific path that, emerging as the law of faith, opposes the law of works, converging to justification as God's justice. Thus, if faith is a concession from God in a movement that contains the idea of predestination, such characterization does not imply, however, an operation that exempts the human being from the responsibility of the decision-making act but consists in the fact that the referred possibility it maintains absolute dependence on the God's grace and, thus, constitutes an event in which the decision can only emerge as a gift from God.

Keywords: Rudolf Bultmann; Apostle Paul; faith; justification; God's grace

\section{Aspectos Introdutórios}

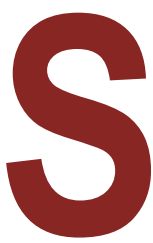

e o Apóstolo Paulo encerra a condição histórica de fundador da teologia cristã, segundo Rudolf Bultmann, que atribui um papel determinante ao seu trabalho de transformação dos elementos teológicos que, inter-relacionados, se mantinham subjacentes ao querigma da igreja do cristianismo helenista, a justificação emerge como o conceito principal da teologia do Novo Testamento de Bultmann em uma construção que, baseada na oposição da perspectiva do Apóstolo Paulo em relação à Lei e às obras que prescreve e à ideia de que Deus não toma o pecador como inocente, nem tampouco o declara como tal, converge para as fronteiras que assinalam a justificação dos pecadores enquanto ato salvífico da graça de Deus que traz a fé enquanto obediência e decisão e guarda raízes na justiça de Deus. 
Dessa forma, se justificar, de acordo com a terminologia jurídica do Antigo Testamento, consiste no ato do juiz que declara a inocência de um indivíduo, absolvendo-o no tribunal, a justificação constitui-se um reconhecimento do direito e da honra conferida ao indivíduo em sua inocência através do pronunciamento implicando um julgamento justo, alcançando a condição de uma espécie de perversão à medida em que o sujeito absolvido é propriamente culpado, convergindo para uma construção que, em virtude do contexto histórico-cultural do direito hebraico, guarda, em última instância, sentido negativo, haja vista que se circunscreve à declaração de que um determinado indivíduo não é culpado.

Se a justificação encerra absolvição e perdão do pecado através de uma construção teológico-forense que converge para as fronteiras que assinalam a incompatibilidade absoluta envolvendo justiça e pecado, é a concepção do Apóstolo Paulo acerca do pecado e da condição do ser humano em relação ao poder do pecado que possibilitará a elaboração de uma doutrina capaz de mostrar a impotência total do ser humano de alcançar justiça diante de Deus enquanto justificação se não for por intermédio do próprio Deus, na medida em que até a Lei se torna inoperante e ineficaz em um movimento que demonstra que a obediência que lhe é devida e a realização das obras que prescreve consistem em observâncias que, resultando na pretensão dos praticantes no sentido de assegurar por si mesmos, pelas suas próprias forças e recursos, a justificação como autojustificação, não guardam equivalência concernente à fé, que se impõe como um princípio irreconciliável no tocante às obras da Lei.

Nesta perspectiva, baseado no pensamento teológico de Bultmann e na sua hermenêutica existencialista, o artigo se detém na justificação e na sua relação com a fé como evento escatológico enquanto obediência e decisão fundada no ato da graça de Deus segundo a teologia do Apóstolo Paulo através de uma construção que recorre aos principais especialistas e pesquisadores do Novo Testamento, tais como Helmut Koester, Werner Georg Kümmel e Leonhard Goppelt, principais representantes do método histórico-crítico, além de Herman Ridderbos e a sua obra fundamental envolvendo o Apóstolo Paulo, a saber, "A teologia do apóstolo Paulo". 
Dessa forma, o artigo se detém na condição do ser humano em relação ao pecado segundo o Apóstolo Paulo em Bultmann, assinalando o caráter absoluto do domínio exercido pelo poder do pecado em um processo que subjuga todos os seres humanos à escravidão e se lhes atribui a condição de carnais através de uma construção teológica que concebe a entrada do pecado no mundo pelo pecar e converge para sublinhar que a transgressão ou a desobediência de Adão consiste na transgressão do mandamento divino em um movimento que implica o despertamento do pecado que trazia em si em estado latente, como possibilidade.

Se a obediência aos mandamentos de Deus e boas obras convergem para as fronteiras da "justiça" em uma construção teológico-religiosa que atribui a condição de "justo" ao judeu cujo esforço se impõe no sentido de cumprir as prescrições e observâncias da Lei, Bultmann salienta que o Apóstolo Paulo defende a "justiça de Deus" como objeto de revelação que se mantém à parte da Lei em um processo que se contrapõe à justiça que traz como fundamento a Lei, tendo em vista o caráter pecaminoso da própria atitude que encerra a tentativa de garantir a justiça por intermédio das obras e sob a acepção de um direito enquanto resultante de sua realização.

Nesta perspectiva, o artigo assinala a impossibilidade de justificação diante de Deus por intermédio das obras da Lei em uma construção teológica que se contrapõe ao judaísmo e à atitude pecaminosa característica que emerge no cumprimento dos mandamentos e na realização das obras que prescreve enquanto produção ético-religiosa capaz de proporcionar justificação, na medida em que a justiça de Deus consiste em um puro presente, convergindo para as fronteiras que encerram como razão da justificação a graça de Deus em um processo que, concomitantemente com a fé, se contrapõe às obras da Lei.

Dessa forma, detendo-se na fé enquanto obediência e decisão fundada no ato da graça de Deus segundo a teologia do Apóstolo Paulo em Bultmann, o artigo mostra que, se a graça constitui um ato escatológico e evento escatológico que encerra uma ação de Deus em sua absoluta liberdade, consistindo em um acontecimento que demonstra a absoluta incapacidade do ser humano e a sua total impotência diante de si mesmo no sentido de alcançar a sua própria salvação, 
o ato salvífico de Deus implica fé enquanto obediência que em sua autenticidade, se sobrepõe ao caráter de uma obra, escapando ao sentido que os escritos rabínicos atribuíam, inclusive, ao exemplo de fé de Abraão, como fé nas promessas enquanto obra da Lei.

Assim sendo, o artigo sublinha que, de acordo com o pensamento teológico do Apóstolo Paulo, segundo Bultmann, a fé consiste em renúncia às obras e encerra obediência em sua radicalidade e o ato de decisão em um movimento que se sobrepõe à justiça própria e converge para as fronteiras que implicam a justiça de Deus através de uma concepção de justiça que, sob a égide escatológico-forense, se impõe ao ser humano imediatamente, no tempo atual ou no presente. Tal concepção se contrapõe ao judaísmo e a sua perspectiva de justiça enquanto um bem da esperança em um movimento que guarda correspondência com a obediência à Lei e à realização das obras que prescreve, haja vista que, segundo o Apóstolo Paulo, a justiça de Deus constitui também uma realidade atual, na medida em que carrega em si tanto a presentidade quanto a futuridade em uma construção teológico-religiosa baseada na fé como evento escatológico em um processo que a encerra como o novo caminho salvífico que, emergindo como a lei da fé, se contrapõe à lei das obras.

\title{
Da condição do ser humano em relação ao poder do pecado segundo a teologia do Apóstolo Paulo em Bultmann
}

\author{
Se pecado é o almejar errado do ser humano e se ele consiste em conduzir \\ a vida кат்́ бápка [segundo a carne], isto é, em viver a partir do criado, do \\ natural-terreno e passageiro, então o pecado conduz à morte com necessidade

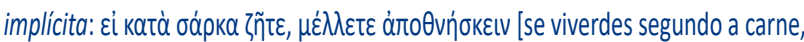 \\ havereis de morrer] (Rm 8.13). (BULTMANN, 2008b, p. 307, grifos do autor)
}

Submetendo todos os seres humanos à escravidão, o domínio exercido pelo poder do pecado tem caráter absoluto, haja vista a condição de carnal do ser humano, o que implica uma qualificação que se sobrepõe ao viver na carne ${ }^{l}$ en-

1. Cabe sublinhar que, segundo Herman Ridderbos, "Bultmann rejeita a visão de que sua idéia denota apenas a 'natureza sensual' do homem ou algo desse tipo. Antes, a 'carne' tipifica todo o modo de existência do homem. Em sua visão, ele parte do significado de "carne" como uma designação da esfera do visível, do 'disponível', aquilo que se encontra à sua 'disposição' (o tangível) e, assim, do transitório e temporal.” (RIDDERBOS, 2004, p. 110) 
quanto "viver humano-natural" e converge para as fronteiras que envolvem viver segundo a carne ${ }^{2}$, encerrando a noção de que a incapacidade da lei no sentido de criar vida guarda correspondência com a carne em virtude do viver em questão.

Se a condição de carnal do ser humano atribui ao pecado o caráter de latente, como possibilidade, a sua realização ou concretização implica a sedução no sentido de que queira obter a vida oferecida pela obediência total à Lei por intermédio de seu próprio esforço em uma construção que assinala que a intenção da exigência da lei e do seu mandamento, como no caso do "não cobiçarás", é a libertação do ser humano do "querer dispor sobre si mesmo" (BULTMANN, 2008b, p. 311).

Por certo, o pecado não consiste na existência "carnal", natural e transitória como tal, mas sim em permitir-se ser determinado pela "came", como esta foi qualificada. Isso ocorre quando o homem vive "segundo a carne", ou seja, permite-se ser tentado a buscar dentro dessa esfera da sua vida, sua felicidade e sua liberdade. O que está envolvido não é apenas o desejo de coisas materiais, mas também todo esforço no sentido de adquirir para si uma base para a vida, vantagens e mérito a partir daquilo que se encontra ao alcance das possibilidades humanas, e que o indivíduo tem à sua disposição. (RIDDERBOS, 2004, p. 110)

Sobrepondo-se ao caráter de uma maldição que desde os tempos primitivos se impõe a todos os seres humanos, a universalidade do pecado guarda raízes nas fronteiras do caráter de culpa do pecado enquanto experiência em uma construção teológica que escapa à concepção de uma universalidade que se impõe como uma qualidade inata ao ser humano através de um movimento que encerra uma sensualidade que emerge da sua matéria constitutiva, tornando-se irredutível também à condição de consequência de uma fatalidade dos tempos primordiais, ambas as perspectivas correspondentes ao pensamento gnóstico.

2. Conforme explica Ridderbos, segundo Bultmann, “esse 'viver segundo a came’ é a forma básica e a síntese do pecado humano. E, ao mesmo tempo, a miséria do homem. Tomando por base essa vida segundo a carne, o homem jamais pode ser 'ele mesmo', seu destino como homem, sua verdadeira 'existência'. Torna-se escravo daquilo que ele pensou que poderia lhe oferecer segurança (securitas).” (RIDDERBOS, 2004, p. 110-111) 
Detendo-se no fato da universalidade do pecado3 ${ }^{3}$ o Apóstolo Paulo elabora uma construção teológico-religiosa que, antepondo à sua exposição enquanto tal a expressão da justiça da fé sem obras ${ }^{4}$, não estabelece como fundamento uma causa que se imponha pela sua precedência ou anterioridade ao efetivo pecar do ser humano através de uma perspectiva que encerra a noção de que a dissidência em relação ao Criador enquanto pecado original traz como efeito punitivo o pecado sob a acepção de uma entrega da criatura ao pecado por Deus ${ }^{5}$, convergindo para uma disposição cuja tendência implica as faltas morais ${ }^{6}$. Dessa forma, escapando à matéria ou à fatalidade enquanto base originária, o pecado original, segundo Bultmann, implica a dissidência em relação a Deus em um movimento que envolve a sua repetição em cada momento do tempo presente diante da possibilidade do conhecimento de Deus que se dispõe ao ser humano em cada momento do tempo presente.

"Portanto, assim como por um só homem entrou o pecado no mundo, e pelo pecado, a morte, assim também a morte passou a todos os homens, porque todos pecaram" (BÍBLIA DE ESTUDO DE GENEBRA, Rm 5.12, 1999, p. 1325). Concebendo a entrada do pecado no mundo pelo pecar, o Apóstolo Paulo assinala que a transgressão ou a desobediência de Adão consiste na transgressão do mandamento divino em um movimento que implica o despertamento do pecado que trazia em si em estado latente, como possibilidade, convergindo para as fronteiras que encerram uma construção teológico-religiosa que escapa às ideias gnósticas, na medida em que não assinala uma causa que se imponha

3. Nesta perspectiva, cabe salientar que em Rm 5.12-19 o Apóstolo Paulo elabora uma construção teológica que, baseada no mito gnóstico, segundo Bultmann, deduz a universalidade do pecado do pecado de Adão e encerra a ideia do "pecado hereditário", convergindo para a descrição da maldição que se impõe à humanidade adâmica.

4. Cf. Rm 1.18-3.20.

5. Cf. Rm 1.24-31.

6. "Para a doutrina judaica da pecaminosidade humana universal, é particularmente importante a idéia da predisposição para o bem e para o mal (yêser) dentro do homem. Estas são consideradas como sendo referentes à natureza humana e, portanto, criadas por Deus. É, então, a vocação moral de todo homem, por meio da força do pendor para o bem e com a ajuda da lei, vencer o pendor para o mal. No Manual da Disciplina da comunidade de Qumran essa doutrina pode ser encontrada na idéia de dois espíritos, um de luz e outro de escuridão, ambos criados por Deus, sendo que o homem se encontra posicionado entre os dois e compelido a escolher (1QS III, 13ss). Em outras passagens, fala-se de um gérmen ou raiz do mal que deve ser vencido pela lei." (RIDDERBOS, 2004, p. 139-140) 
pela anterioridade e seja instituída como fundamento do pecado de Adão (tal como a matéria constitutiva de Adão ou propriamente Satanás), e se sobrepõe à doutrina rabínica, haja vista que nem tampouco recorre ao "impulso mau" como sua base formal.

Convergindo para a condição de consequência de uma fatalidade em uma construção que escapa à responsabilidade da humanidade, o pecado da humanidade guarda correspondência com o pecado de Adão, constituindo-se uma derivação em um movimento que, dessa forma, atribui o caráter de pecadores aos seres humanos que pecam sob a acepção forense, não havendo possibilidade de imputação de culpa de acordo com o significado ético senão como ato culposo segundo a lei.

Dessa forma, se a obediência de Cristo implica a possibilidade da vida enquanto realidade que se impõe aos crentes pela fé, a transgressão ou desobediência de Adão converge analogamente para as fronteiras que encerram a possibilidade do pecado e da morte para a humanidade adâmica em um movimento cuja concretização guarda correspondência com o ato culposo responsável através de uma construção teológico-religiosa que se mantém sob a égide envolvendo a condenação universal da humanidade adâmica ao pecado e à morte ${ }^{7}$.

Como a vida humana é vida no convívio, a confiança mútua é destruída por uma só mentira e instala-se a desconfiança - e com isso o pecado; por um ato de violência se provoca violência como defesa e o direito é colocado a serviço do interesse do indivíduo como violência organizada - e assim por dian-

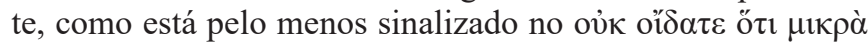

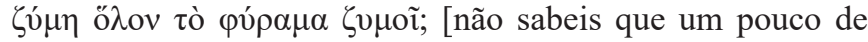
fermento leveda toda a massa?] (1Co 5.6). Assim cada qual se encontra num mundo em que cada um está preocupado consigo mesmo, cada um insiste em seu direito, cada um luta por sua existência, e a vida se torna uma luta de todos contra todos, ainda que essa luta seja conduzida de modo involuntário. (BULTMANN, 2008b, p. 315)

A co-responsabilidade de cada ser humano, eis o que se impõe por meio da transgressão concreta enquanto existência determinada pelo pecado hereditário 
e pela experiência que implica o nascimento nas fronteiras de uma humanidade que permanece sob a égide do erro como inclinação básica em uma construção teológico-religiosa que assinala a influência inescapável do pecado diante do qual o mandamento divino como um conteúdo que se dispõe à decisão que implica a obediência como autossuperação em um processo que guarda raízes, em última instância, em uma autocompreensão pecaminosa.

\section{Da condição da justiça como justiça de Deus segundo a teologia do Apóstolo Paulo em Bultmann}

Se para o judaísmo a condição para a justiça envolve a obediência à Lei e a consequente realização de obras que prescreve ${ }^{8}$, o Apóstolo Paulo defende a ideia da impossibilidade de justificação diante de Deus por intermédio das obras da lei através de uma construção teológico-religiosa que traz como base escriturística o exemplo historial de Abraão, o qual não obteve justiça por intermédio de suas obras senão pela fé, constituindo-se a prova que assinala a justiça que advém "à parte das obras da lei" e sob a fé e que implica "justiça da fé" e "justiça a partir de Deus na fé" em contraposição à "justiça com base na lei" e à "justiça a partir da lei"'.

Consistindo na atitude pecaminosa característica do judeu no cumprimento da lei através da realização das obras que prescreve, à vanglória o Apóstolo

8. "No judaísmo rabínico, a 'justiça' se identificava completamente com a conformidade à $\rightarrow$ Lei. Muitas das leis, mormente as leis cerimoniais, já não eram relevantes na forma em que estavam, mas, segundo os rabinos, tinham a intenção do treinar os homens na obediência e, especialmente, providenciar uma maneira para os homens adquirirem mérito aos olhos de Deus. A paixão pela obediência agora ficou transformada em esforço em prol do mérito, para garantir sua própria participação no reino de Deus. As obras de caridade e as obras de misericórdia eram consideradas especialmente meritórias, sendo que as primeiras ( $s f d \tilde{q} q d h)$ abrangiam tudo quanto podia ser feito mediante o gasto de dinheiro, tal como: alimentar os famintos, vestir os nus, dando de beber aos com sede, etc., enquanto as obras de misericórdia eram aquelas que exigiam um esforço, como, por exemplo: condoer-se com os enlutados, e visitar os que estão doentes ou encarcerados (cf. Mt 25:35-36).” (SEEBASS In: BROWN; COENEN, 2000, p. 1123-1124)

9. "Foi, porém, precisamente no assunto de praticar a Lei que Israel fracassara (Rm 9:31), porque o homem não pode fazer a vontade de Deus a não ser que a justiça de Deus tenha alcançado, dominado e envolvido completamente. Senão, o pecado usurpa a Lei (Rm cap. 7), e o homem está indefeso contra ele, porque o pecado não é primariamente maus atos ou más inclinações, mas, sim, a luta que o homem faz para merecer sua própria retidão e justificação ( $R$ m 10:3). Sendo assim, somente o homem que morreu para o pecado e, portanto, é justificado (Rm 6:7) pode fazer a vontade de Deus (Rm 6:10)." (SEEBASS In: BROWN; COENEN, 2000, p. 1128) 
Paulo contrapõe a fé como a sua renúncia radical em uma construção que converge para as fronteiras que encerram a impossibilidade de que a justiça se torne objeto de conquista do ser humano em virtude do seu esforço próprio, na medida em que escapa à condição de um direito que porventura se dispõe como resultado de sua realização, consistindo, em suma, em um puro presente ${ }^{10}$.

Caracterizando como razão da justificação a graça de Deus, esta, concomitantemente com a fé, se contrapõe às obras da lei, assim como à lei, convergindo para as fronteiras que assinalam que o recebimento da promessa guarda correspondência com a fé e a sua justiça, sobrepondo-se à lei sob cuja égide não há possibilidade de que se cumpra ou se concretize, na medida em que a lei produz ira em um movimento que tende à transgressão, confirmando que a promessa é dada à fé através de um processo que tem valor justamente por essa razão, $a$ partir da fé, para que seja segundo a graça.

Essa é a razão por que provém da fé, para que seja segundo a graça, a fim de que seja firme a promessa para toda a descendência, não somente ao que está no regime da lei, mas também ao que é da fé que teve Abraão (porque Abraão é pai de todos nós, como está escrito: Por pai de muitas nações te constituí.), perante aquele no qual creu, o Deus que vivifica os mortos e chama à existência as coisas que não existem. (BÍBLIA DE ESTUDO DE GENEBRA, Rm 4.16, 1999, p. 1324)

Sobrepondo-se à obrigação imposta por qualquer tipo de pretensão humana, a graça constitui um ato escatológico e evento escatológico que encerra uma ação de Deus em sua absoluta liberdade, tornando-se irredutível ao caráter de uma mentalidade magnânima, convergindo para as fronteiras que assinalam a condição de origem da justiça em uma construção que encerra a anulação da graça em face da atitude do ser humano que por intermédio de suas realizações queira se vangloriar diante de Deus.

Contrapondo-se às obras enquanto práticas que encerram em si a fundamen-

10. Nesta perspectiva, Ridderbos defende que "pode-se determinar que para Paulo a luta do homem a fim de obter sua justificação diante de Deus por meio das obras da lei está condenada a fracassar não apenas porque o homem não é capaz de cumprir a lei conforme Deus requer dele, mas porque já é fundamentalmente pecaminoso o desejo de garantir para si próprio a retidão e a vida; na verdade, esse é o pecado humano par excellence." (RIDDERBOS, 2004, p. 150) 
tação de direitos diante de Deus, conforme pressuposto na relação com Deus instaurada pelo judaísmo através da exigência da obediência à Lei e aos seus preceitos, o Apóstolo Paulo sublinha a graça e o contraste envolvendo a obrigação e os méritos que representa em uma construção teológico-religiosa que assinala a impossibilidade de justificação do ser humano perante Deus, na medida em que tal processo tende a se tornar uma autojustificação, convergindo para as fronteiras que envolvem uma atitude que demonstra a intenção de subsistir por si próprio perante Deus.

Assim Bultmann, por exemplo, escreve que o significado histórico-redentor da lei consiste no fato de que ela leva o homem a pecar; não apenas, porém, porque estimula seu desejo pela transgressão, mas também por oferecer-lhe a oportunidade máxima de viver como um pecador ao converter sua resistência à lei na luta pela justificação própria por meio do cumprimento dos mandamentos. (RIDDERBOS, 2004, p. 152)

Escapando à condição que envolve a amabilidade e a bondade de Deus em um movimento que implica a sua manifestação diante da fraqueza do ser humano e da sua incapacidade de corresponder aos preceitos éticos e manter uma conduta condizente com os atributos gerais de Deus, a graça converge para as fronteiras que encerram a possibilidade de decisão em relação a Deus através da obediência da fé em uma construção que demanda a submissão absoluta e a rendição total do ser humano como irremediável pecador, haja vista a necessidade de reconhecer o seu estado, renunciando à soberba e à autoilusão que se impõe ao esforço instaurado no sentido de depender de si mesmo e viver de si mesmo em um movimento que guarda raízes no seu orgulho e autossuficiência ${ }^{11}$.

Sobrepondo-se à noção de justiça característica do judaísmo no movimento

11. Cf. Rm 3.27. "Nesta perspectiva, a disposição de Abraão no sentido de sacrificar o seu filho em função de uma ordem divina em um processo que assinala uma contradição entre a promessa da descendência e o dever de obedecer a Deus converge para uma relação que implica uma absoluta confiança da criatura em face do Criador na medida em que a obediência irrestrita do patriarca encerra a negação da sua autonomia e guarda raízes nas fronteiras que envolvem uma fé total e um amor incondicional, contrapondo-se à conduta de Adão como modelo e protótipo da humanidade na sua condição originária no Jardim do Éden e instaurando o princípio da verdadeira religião e da superação do pecado que, no sentido de alienação, ao seu exercício compete e cuja tendência corresponde, em última instância, ao autogoverno e à autodeterminação." (MARIANO DA ROSA, 2019, p. 468) 
que exige obediência à Lei e realização das obras que prescreve para o seu cumprimento enquanto atitude humana em sua relação com Deus, a concepção de justiça que guarda raízes nas fronteiras da graça de Deus traz a condição de um presente de Deus, perfazendo, em suma, a justiça de Deus ${ }^{12}$, na medida em que escapa à Lei e tem Deus como origem, sendo fundada na fé.

\section{Da fé enquanto obediência e decisão fundada no ato da graça de Deus segundo a teologia do Apóstolo Paulo em Bultmann}

Encerrando a atitude do ser humano enquanto movimento que possibilita o recebimento da justiça de Deus e condição sine qua non para a sua experiência como dádiva, à fé $(\pi i ́ \sigma \tau \eta)^{13}$ se impõe o ato salvífico divino em um processo que traz em sua estrutura a obediência que envolve o reconhecimento do Crucificado como kúpro $\varsigma^{14}$ através de uma construção que demanda uma ruptura com o modus vivendi característico de sua existência e converge para as fronteiras que implicam a confissão, na medida em que guarda correspondência com a ação salvífica de Deus como objeto, se sobrepondo à concepção de um determinado estado da alma que em sua perfeição seja capaz de assegurar por si a salvação.

A fé é obediência, porque nela o orgulho do ser humano é quebrado. Aquilo que, a rigor, é evidente torna-se o mais difícil para o ser humano no seu orgulho. Ele não quer desfazer-se da carga sob a qual se tortura; ela tornou-se parte do seu si-mesmo, até tornou-se o seu si-mesmo. Ele acha que se perderá se se entregar, se entregar-se como aquele que ele mesmo fez de si. Mas ele deve perder-se para então encontrar-se de fato. Deve inclinar-se, humilhar-se, deixar seu orgulho de lado, para assim encontrar a si mesmo. (BULTMANN, 2001, p. 254, grifos do autor)

12. "Um conceito central na teologia de Paulo é a $\rightarrow$ justiça de Deus (Rm 1:17, 21-22; 9:30; 10:3; 2 Co 5:21; Fp 3:9). É uma justiça que julga, mas também que salva. Deus é justo quando condena a humanidade pecaminosa. E igualmente justo, porém, quando outorga a Sua graça perdoadora àqueles que creram em Cristo e na salvação obtida por meio dEle. Por amor a Cristo, em Quem o próprio Deus ofereceu o sacrifício de expiação pela $\rightarrow$ culpa da humanidade, não conta contra ela os seus pecados; pelo contrário, pronúncia justas as pessoas. Desta forma, a dikaiosynè theou forma o fundamento da teologia paulina da $\rightarrow$ justificação (cf. L. Morris, The Apostolic Preaching of the Cross, 1963, 273 e segs.; D. Hill, Greek Words and Hebrew Meanings, 1967, 82-162)." (SCHNEIDER In: BROWN; COENEN, 2000, p. 567)

13. Pístis.

14. Kýrios. 
Convergindo para a autenticidade que a obediência implicada na Lei se torna incapaz de gerar em um movimento que se esgota na justiça própria das obras, a fé encerra uma atitude de negação de si mesmo enquanto renúncia da autocompreensão determinante do seu modus vivendi em um processo cuja dinâmica, longe de se circunscrever a si como um evento fundado em si próprio, demanda a mudança do sentido volitivo e guarda oposição total em relação à dependência de si no que tange à salvação, invalidando a autoexaltação, a vanglória e o orgulho como seus efeitos inevitáveis ${ }^{15}$.

Consistindo em um acontecimento que demonstra a absoluta incapacidade do ser humano e a sua total impotência diante de si mesmo no sentido de alcançar a sua própria salvação, o ato salvífico de Deus implica fé enquanto obediência que em sua autenticidade se sobrepõe ao caráter de uma obra ${ }^{16}$ que, como produto da vontade, assume a condição de um objeto de autoexaltação através de um movimento que torna impossível a renúncia a si mesma, na medida em que a sujeição ou submissão à Lei se circunscreve às fronteiras de uma atitude que escapa ao seu verdadeiro sentido:

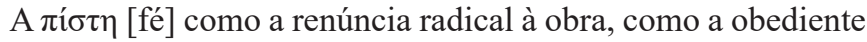
sujeição ao caminho da salvação determinado por Deus, como a aceitação da cruz de Cristo, é o livre ato da obediência, no qual se constitui o novo eu no lugar do velho. (BULTMANN, 2008b, p. 385)

15. "A causa real e mais profunda para a rejeição da parte dos judeus do Cristo crucificado encontra-se no fato de que a cruz priva o homem de sua própria justificação. O skandalon da cruz, portanto, deve ser mantido e não se pode fazer um acordo com o homem que é ofendido por ele ao permitir que, no final das contas, ele contribua em parte para a sua retidão (circuncisão em Gl 5.11)." (RIDDERBOS, 2004, p. 149-150)

16. "Nesta perspectiva, a fé prototípica de Abraão converge para a construção de um acontecimento que guarda capacidade de funcionar como a matriz simbólica do drama da redenção da humanidade na medida em que se o patriarca hebreu protagoniza o papel que ao Pai Celestial caberá no ato de oferecimento do Seu próprio Filho em sacrifício, Isaque demonstra disposição de obedecer até a morte, tal como Jesus Cristo que, embora na condição de Deus-Homem, submete-se até o fim ao propósito de Deus-Pai, que demanda a sua crucificação para a remissão dos pecados e para a salvação de todo aquele que crê, configurando a aparição do carneiro um gesto salvífico de Deus no sentido de prover o sacrifício substitutivo de um cordeiro inocente em função do resgate do gênero humano em um processo que, prenunciando a ressurreição do Filho de Deus, culmina na restauração da vida de Isaque em um movimento que encerra a sua "devolução" ao patriarca no clímax do ritual do sacrifício no Monte Moriá.” (MARIANO DA ROSA, 2018b, p. 173, grifos meus) 
Dessa forma, convergindo para as fronteiras que encerram as obras e implicam, consequentemente, a justiça própria, a obediência à Lei encerra uma relação envolvendo a vontade que se mantém sob o horizonte da formalidade e que, desse modo, não guarda capacidade de superar a condição de exterioridade objetiva que, por sua natureza, prescinde da interioridade e da dialética subjetivo-existencial que tende à essencialização do ser humano enquanto existência em sua singularidade, consistindo a fé enquanto obediência um movimento que implica uma decisão que, como um ato no verdadeiro sentido do termo, emerge para possibilitar que o ser humano apareça como si próprio.

Opondo-se à perspectiva que, baseada no direito codificado, institui uma relação com Deus que converge para as fronteiras do direito, Jesus exige uma obediência que implica um exercício radical e autêntico em um processo que encerra o ser humano em sua totalidade, haja vista que o controle e o domínio sobre a ação e a conduta, pressupostos da lei, não guarda capacidade de fundamentar a relação com Deus, na medida em que as fronteiras nas quais tal comportamento guarda raízes, a saber, a vontade humana, escapa ao seu poder e determinação. (MARIANO DA ROSA, 2020, p. 172)

Sobrepondo-se ao caráter de uma "experiência emocional" e à condição de um "estado da alma" ou uma disposição ou uma virtude, a fé implica obediência autêntica em um processo que, longe de consistir em um alvo ou uma meta, emerge como ato, consistindo no princípio do novo ser e do novo modo de existência, fundamentando a nova vida.

Sim, o que a fé não tem de obra, isso ela tem de ato; e agora deve estar claro em que consiste a diferença. Na obra, continuo sendo aquele que sou; eu a extraio de mim, eu me posto ao seu lado, posso avaliá-la, refugá-la ou ficar orgulhoso dela. No ato, torno-me alguém; nele encontro o meu ser, vivo nele e não me posto ao seu lado. Se eu pretendesse olhar para mim e para o meu ato, destruiria o ato como ato e o degradaria à condição de obra. (BULTMANN, 2001, p. 256, grifos do autor)

Se a obediência à Lei converge para as fronteiras que guardam raízes na vontade e na sua imposição como tal em um processo que atribui caráter de obra a sua produção, a obediência da fé, longe de guardar um sentido similar e perfazer a condição da justificação, encerra primeiramente uma equivalência entre 
os seus termos constitutivos em um processo de identificação que tende a expor a dinâmica do movimento e destituí-lo do significado de um resultado de uma construção volitiva em sua relação com um determinado sistema ético-religioso, constituindo-se antes um princípio que, embora esteja atrelado à vontade como decisão existencial, não corresponde à salvação senão em virtude do fato de possibilitar a experiência da justificação como justiça de Deus ${ }^{17}$ na atitude que envolve o seu recebimento pelo ser humano como dádiva.

Exigindo uma obediência incondicional, Jesus, em sua pregação, usa a imagística de uma criança em sua incapacidade cognitiva para assinalar o paradigma que o ser humano deve corresponder na sua relação com Deus, convergindo para um estado que ignora direitos e méritos e, consequentemente, escapa à condição que tende ao orgulho e à soberba, na medida em que a promessa em face da obediência guarda correspondência com uma prática incondicional cujo exercício, radical e autêntico, se sobrepõe às fronteiras que implicam a expectativa de recompensa. (MARIANO DA ROSA, 2020, p. 173)

"Fé é renúncia às obras; mas é ato de decisão. É o ato paradoxal de renúncia a qualquer obra, ciente de que a graça só pode ser recebida nessa renúncia" (BULTMANN, 2001, p. 256, grifo do autor). Caracterizando-se como renúncia às obras, a fé envolve a obediência em sua radicalidade e o ato de decisão em um movimento que se sobrepõe à justiça própria e converge para as fronteiras que encerram a justiça de Deus, consistindo em um conceito que traz em sua constituição o arrependimento e a penitência como elementos que, contudo, se mantêm submetidos aos aspectos determinantes da fé, a saber, obediência e decisão ${ }^{18}$, que perfazem a sua estrutura identitária em uma correlação que reúne

17. Convém salientar que "especialmente os escritos de Qumran atestam, em vários lugares, a iniciativa de Deus no processo de justificação. Desde o seio materno, Deus predestinou o ímpio para o dia da perdição, o justo para o tempo da graça, a fim de que pudesse viver na aliança de Deus $(1 \mathrm{QH} 15,15 \mathrm{~s})$. Deus formou o espírito; d'Êle vem o caminho de todo ser vivo $(15,22)$. O homem é justo por uma participação na justiça de Deus, que se manifesta nas obras (1QH 14,14-16). Quando o homem tropeça, devido à ruindade da carne, a sua justificação deve-se à justiça de Deus (1QS 11,12). A palavra justificação ganhou o sentido de perdão e reconciliação $(11,13-22)$.” (SJÖBERG et al. In: DICIONÁRIO, 2014, p. 862)

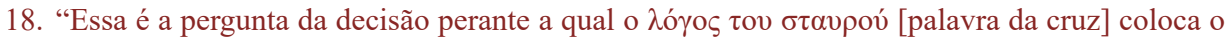
ouvinte, se ele quer reconhecer que Deus institui um crucificado como senhor; se com isso quer reconhecer a exigência de, na renúncia de sua autocompreensão que teve até agora, tomar sobre si a cruz, deixar que ela se torne o poder determinante de sua vida, de deixar-se crucificar com Cristo (1Co 1.18-31; Gl 6.14, cf. 5.24).” (BULTMANN, p. 370) 
também "confessar" e "crer" através de um liame de correspondência que assinala a sua condição de imbricação concernente à salvação de Deus em Cristo ${ }^{19}$. "Se, com a tua boca, confessares Jesus como Senhor e, em teu coração, creres que Deus o ressuscitou dentre os mortos, serás salvo." (BÍBLIA DE ESTUDO DE GENEBRA, Rm 10.9, 1999, p. 1335)

Sobrepondo-se ao caráter de "piedade" ou confiança em Deus, a fé implica a aceitação de uma palavra em um processo que encerra o conteúdo que emerge da correlação que envolve falar da fé2 $e^{20}$ e que se ouve da $f^{21}{ }^{21}$, convergindo para o que se designa como fé do evangelho ${ }^{22}$ através de um movimento que encerra necessariamente um saber, cuja apropriação demanda uma autocompreensão em uma construção que impõe ao saber (conhecimento) ${ }^{23}$ a capacidade de fundamentar a fé, simultaneamente tornando-o resultado da fé em sua produção, na medida em que, nesta correlação, constitui-se, em suma, a identidade envolven-

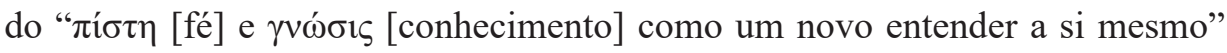
(BULTMANN, 2008b, p. 387).

Encerrando exigência e promessa como ato da graça de Deus, a palavra consiste em Kerygma ${ }^{24}$ em um movimento que envolve pessoas e transpõe as fronteiras que envolvem relato e doutrina implicando acontecimentos históricos e fatos concretos que convergem para a possibilidade de que sejam "considera-

19. Nesta perspectiva, torna-se relevante o comentário de Goppelt sobre a interpretação de Bultmann: "Na interpretação existencial, a cruz só pode ser interpretada como pergunta no seguinte sentido: 'Quer o homem desistir de sua antiga autocompreensão e passar a compreender-se inteiramente a partir da graça de Deus', ou seja, no sentido de Rm 6,11? Assim, todavia, a cruz bem como a vida do homem fica restritas a uma autocompreensão. No entanto, o homem vive na História, em todas as relações nas quais Paulo coloca a cruz. Vive sob as leis desse mundo e na esperança de um futuro diferente (Rm 3-5), num 'corpo do pecado' e 'da morte' (Rm 6,6; 7,24). A interpretação da cruz como morrer com Cristo para com ele viver está orientada em especial para essa área antropológica" (GOPPELT, 2002, p. 344-345).

20. Cf. Rm 10.8

21. Cf. Gl 3.2,5

22. Cf. Fp 1.27

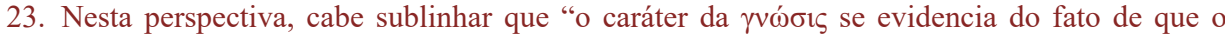

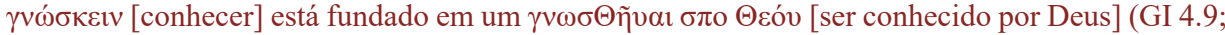
1Co 13.12)." (BULTMANN, p. 388).

24. Cabe sublinhar que "escutar as escrituras como Palavra de Deus significa escutá-las como uma palavra que me é dirigida, como um Kerygma, como uma proclamação. Neste caso, minha compreensão das escrituras não é imparcial, senão que é minha resposta a uma chamada." (BULTMANN, 2008a, p. 57) 
dos verdadeiros sem transformação existencial" (BULTMANN, 2008b, p. 388), haja vista que é a fé que se impõe como a sua aceitação em uma construção que implica obediência, reconhecimento e confissão.

Contrapondo-se às obras como produção da vontade enquanto obediência à Lei em um processo que as torna fundamento da justificação e converge para a justiça própria, a fé implica obediência, reconhecimento e confissão em um movimento que encerra a fé como tal em virtude da sua relação com a graça ${ }^{25}$ de Deus, que se impõe como ato no Kerygma como exigência e promessa.

Escapando às fronteiras da condição de um estado psíquico, a fé tampouco emerge como processo psíquico, sendo irredutível ao horizonte daquilo que é como ato ou atitude, na medida em que guarda raízes nas fronteiras do ato da graça de Deus em sua precedência e anterioridade ao movimento que implica obediência e simultaneamente confissão enquanto processo que, inter-relacionado ao "crer", envolve o distanciamento de si próprio e a confissão do ser humano que atribui a Deus o que está imbricado em sua existência tanto sob a égide do ser

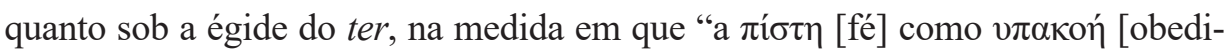

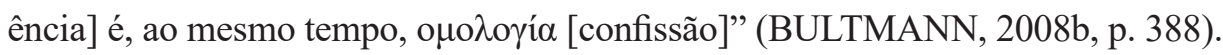

Guardando correspondência com a confissão enquanto prática que funda a fé no ato da graça de Deus, o distanciamento de si mesmo converge para as fronteiras que encerram a esperança, na medida em que, se sobrepondo à condição de um estado de alma, a fé implica uma relação com o futuro.

Se como alvo do crer a justiça guarda raízes na relação do ser humano com Deus, a sua presentidade emerge como escatológica, não se constituindo um estado temporal, sujeito à sua transitoriedade, na medida em que, como possibilidade presente, a justiça sempre se dispõe ao crente sob a acepção de justiça vindoura, escapando ao caráter de uma qualidade inerente, tendo em vista a sua condição, que é a condição do "já justificado", convergindo para as fronteiras que encerram uma esperança que implica a condição de liberdade e abertura para

25. Xópๆ. "Para Paulo, charis é a essência do ato salvífico de Deus mediante Jesus Cristo, que ocorreu na morte sacrificial dEste, como também de todas as suas conseqüências no presente e no futuro (Rm 3:24ss).” (ESSER In: BROWN; COENEN, 2000, p. 911) 
o futuro como uma disposição baseada na obediência da fé em uma construção que assinala como pecado da descrença "querer viver de si mesmo e, na ilusão de poder dispor, tomar o futuro sob seu próprio cuidado" (BULTMANN, 2008b, p. 389).

Imbricada na fé enquanto obediência autêntica e decisão em um movimento que encerra a condição de liberdade e abertura para o futuro, a esperança integra uma unidade que envolve a fé em uma correlação que implica o amor e converge para as fronteiras que abrangem, no caso do amor, o esforço, e, no caso da esperança, a constância, como produção da fée ${ }^{26}$, através de uma construção que traz a correspondência entre tal esperança e o medo em sua constituição identitária, na medida em que a participação do medo tende a assegurar uma relação com a graça de Deus enquanto locus do exercício da fé, visto mantê-la sob a égide de Deus.

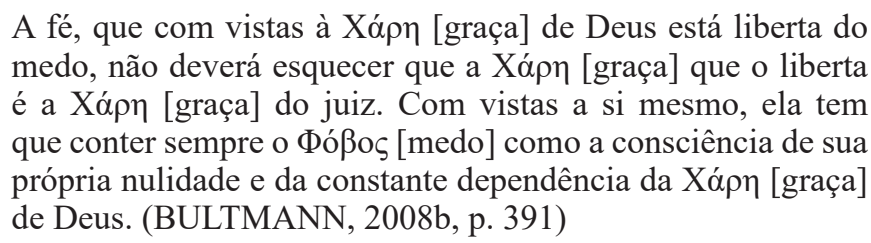

Encerrando a unidade envolvendo esperança e medo, a fé enquanto obediência e decisão converge para as fronteiras que implicam a graça de Deus como fundamento em um movimento cujo sentido guarda correspondência com a consciência da própria condição humana que, sob a égide da nulidade, mantém absoluta dependência de Deus e do seu ato salvífico em Cristo, perfazendo uma construção identitária que, para além do significado negativo do medo nesta relação escatológico-existencial, tende a produzir a consciência da responsabilidade que compete ao crente assumir neste processo em virtude de sua condição de liberdade instaurada pela graça de Deus.

Perfazendo a estrutura identitária e existencial da fé, esperança e temor guardam correlação em uma construção que escapa às fronteiras de um movimento cujo sentido é passível de mudança e alteração constante e incessantemente, convergindo para as fronteiras que encerram a fé como obediência em um processo que, dessa forma, renunciando a si mesmo como base existencial para a 
autoconstituição, guarda dependência absoluta da graça de Deus.

\section{Da fé enquanto obediência e decisão como justiça de Deus segundo o Apóstolo Paulo em Bultmann}

Se encerra a condenação à morte como resultado de um movimento que implica a condição de perda do eu em virtude do seu esforço no sentido de viver de si mesmo, ao ser humano se impõe a obediência da fé como entrega de si próprio a Deus em um processo que converge para as fronteiras que envolvem a conquista do eu como ganho e guarda correspondência com a vida através de um movimento que, segundo a perspectiva teológica do Apóstolo Paulo, pressupõe o "ato de ser justificado", na medida em que a salvação se mantém relacionada à noção de "justiça", conforme o princípio da construção teológico-religiosa da tradição judaica ${ }^{27}$.

Se a justiça de Abraão converge para o recebimento da promessa em uma construção teológico-religiosa que assinala como condição a fé2 ${ }^{28}$ (em função da qual Deus imputa justiça a Abraão ${ }^{29}$ ), aqueles que se tornam justos pela ação de Deus alcançam a salvação em um movimento que implica a fé como obediência

27. "Para o judaísmo, o grande contrapeso da ameaça e do poder do pecado encontra-se na lei dada a Israel. A lei é o meio singular de adquirir para si mérito, recompensa e justiça diante de Deus; é o instrumento dado por Deus para subjugar o impulso perverso e conduzir o bem à vitória. Pode-se dizer com razão, portanto, que, para os judeus, a lei era o meio preeminente de salvação, na verdade, era a verdadeira 'substância de vida'." (RIDDERBOS, 2004, p. 140, grifos meus)

28. Cf. Rm 4.13. "Nesta perspectiva, a experiência de Abraão atribui à fé a condição de fundamento da relação com o Absoluto na medida em que dispensa qualquer tipo de mediação simbólica e converge para situá-la nas fronteiras que envolvem o paradoxo, haja vista que emerge como um acontecimento que implica absoluta dependência de Deus e da sua palavra em um processo que encerra ideias ou noções aparentemente contraditórias, a saber, a promessa de descendência e o sacrifício do filho em holocausto, demandando uma capacidade de obediência que somente pode guardar raízes em uma total confiança no Ser Supremo.” (MARIANO DA ROSA, 2018a, p. 152, grifos do autor)

29. "Ele creu no SENHOR, e isso lhe foi imputado para justiça" (BÍBLIA DE ESTUDO DE GENEBRA, Gn 15,6, 1999, p. 32). “À justificação pela fé atribuída à Abraão diante da promessa do herdeiro, em um processo no qual Deus projeta a sua posteridade às estrelas, impõe-se as suas obras, que convergem para o oferecimento do seu filho Isaque em sacrifício sobre o altar no Monte Moriá em um movimento que envolve a correlação que encerra fé e obras através de um ato que implica certeza e convicção no sentido de substância das promessas de Deus e perfaz um movimento que guarda correspondência com o exercício que implica a posse imediata e a propriedade absoluta da realidade exposta pelo Lógos como a Sua revelação verbal." (MARIANO DA ROSA, 2019, p. 478-479) 
e decisão e traz a vida como ganho através de uma relação que envolve a correspondência entre justiça e salvação e atribui o caráter do bem salvífico à própria justiça.

\begin{abstract}
A justiça não pode mais ser definida como uma capacidade humana; ela pertence exclusivamente a Deus, que revelou sua justiça por meio de Jesus, que confiou apenas em Deus. Deus revelou assim sua justiça por meio da fidelidade de Jesus Cristo. A fé é a realização desse ato justo de Deus, que agora é oferecido como presente a ser dado a todos os homens, tanto judeus como gentios (3,18-31). (KOESTER, 2005, p. 154)
\end{abstract}

Consistindo, em suma, na preocupação dos judeus, justificação guarda condição de paralelismo sinonímico em relação à salvação, convergindo para as fronteiras de uma construção teológica que encerram termos tais como justiça, santificação e redenção como capazes de identificar o estado salvífico, carregando sentidos equivalentes ministério da justificação e ministério do espírito em contraposição às expressões ministério da condenação e ministério da morte, ambas as quais correspondentes, o que implica que "aquilo que foi trazido à luz

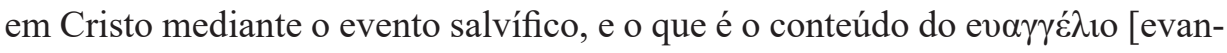

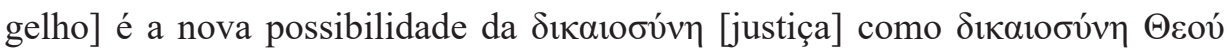
[justiça de Deus] (Rm 1.16s.; 3.21)" (BULTMANN, 2008b, p. 335).

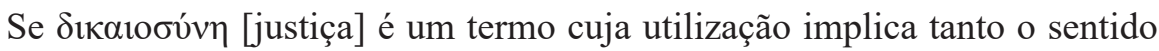
ético quanto o significado forense, sobrepondo-se ao seu aspecto ético a palavra carrega a noção de uma relação em uma construção que, como designação da pressuposição salvífica ou do bem salvífico, se mantém sob a égide forense, assinalando a ideia de que a justiça em questão não se impõe ao ser humano sob a acepção de uma qualidade ética, mas perante o foro diante do qual é responsável, no juízo de outrem, em um processo que envolve a atribuição de tal condição, caracterizando-o como "justo" ou detentor de "justiça" em face do caráter questionável do seu reconhecimento como tal, o que implica, dessa forma, a sua "justificação", constituindo-se o "justo", nesta perspectiva, o estado daquele que recebe absolvição.

É, pois, incontestável que, antes de mais nada, a justificação é sempre um ato forense (Rm 1,23-4,25). De acordo com Rm 
6,17-23, porém, está-se na posse da justificação somente quando se está a serviço da justiça, ou seja, quando se vive a partir dessa relação com Deus! Será justificado aquele que ocupar o lugar que Deus the indica, vale dizer, o que crê. (GOPPELT, 2002, p. 380, grifos do autor)

Obediência aos mandamentos de Deus e boas obras, eis as condições que convergem para a "justiça" em uma construção teológico-religiosa que atribui a condição de "justo" ao judeu cujo esforço se impõe neste sentido, o que implica uma justiça que traz como fundamento a Lei ${ }^{30} \mathrm{em}$ contraposição à qual o Apóstolo Paulo defende a "justiça de Deus" como objeto de revelação que se mantém à parte da Lei: "Mas agora, sem lei, se manifestou a justiça de Deus, testemunhada pela lei e pelos profetas; justiça de Deus mediante a fé em Jesus Cristo, para todos [e sobre todos] os que crêem" (BÍBLIA DE ESTUDO DE GENEBRA, Rm 3.21, 1999, p. 1322).

Convergindo para as fronteiras que encerram a condição envolvendo "crer", a justiça escatológico-forense é atribuída imediatamente, no tempo atual ou no presente ao ser humano, na medida em que a fé enquanto obediência e decisão emerge como pressuposto da justificação enquanto "ser justificado" através de um movimento que, dessa forma, implica salvação em uma construção que assinala o reinado da graça por intermédio da justiça para a vida eterna, haja vista que o "estar Cristo" no ser humano guarda correspondência com o "estar morto" do corpo e simultaneamente com o "estar vivo" do espírito: "Se, porém, Cristo está em vós, o corpo, na verdade, está morto por causa do pecado, mas o espírito é vida, por causa da justiça” (BÍBLIA DE ESTUDO DE GENEBRA, Rm 8.10, 1999, p. 1330) $)^{31}$.

Escapando ao sentido de justiça enquanto "isenção de pecado" em uma construção teológico-religiosa que envolveria a condição de uma perfeição ética, a justiça atribuída ao crente converge para a noção de um ato de Deus que não "toma em conta" o pecado através de um movimento que encerra a presentidade da justiça e se mantém sob a égide escatológico-forense, implicando o paradoxo 
do pronunciamento divino de sua sentença escatológica em relação ao crente no tempo atual ou no presente em um processo que assinala que o evento escatológico se caracteriza como um evento que já é presente ou tem início no presente.

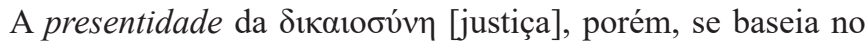
fato de que ela foi "revelada" por meio do evento salvífico realizado em Cristo (Rm 3.21-26; 2Co 5.21; cf. 1Co 1.30). Esse evento salvífico, porém, é o evento escatológico, por meio do qual Deus pôs um termo ao velho curso do mundo e inaugurou o novo éon. Pois, "ao cumprir-se a plenitude do tempo, Deus enviou seu Filho" (GI4.4); assim, pois, "o velho passou", "fez-se um novo", e quem está "em Cristo" é "nova criatura" (2Co 5.17). A antiga aliança foi substituída pela nova aliança

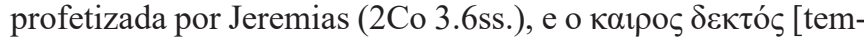
po aceitável] profetizado por Isaías tornou-se presente $(2 \mathrm{Co}$ 6.2). (BULTMANN, 2008b, p. 342, grifos do autor)

Se consiste em uma condição irredutível ao caráter de uma perfeição ética, a justiça guarda o sentido escatológico-forense que converge para a "justificação" do pecador em uma construção na qual Deus torna o ser humano "justo", inocentando-o por intermédio de sua sentença, o que implica a impossibilidade de contato com o pecado que determina a existência escatológica em um movimento que estabelece a correspondência entre "justificados" e "santificados"32.

Dessa forma, a justiça ("ser justificado") na construção teológico-religiosa do Apóstolo Paulo não pode permanecer sob a égide de uma interpretação que não se detenha no sentido escatológico-forense com o qual o termo que o identifica guarda correspondência ${ }^{33}$, na medida em que tal atitude de negligência e omissão, segundo Bultmann, converge para as fronteiras que encerram o equívoco de um idealismo que afirma a justificação como um processo que envolve a recepção na consciência do "princípio da obediência sob a ideia do bem" (BULTMANN, 2008b, p. 342), o que implica a caracterização de justo ao ser

32. Cf. 1 Co $1.30 ; 6.11$.

33. Dessa forma, Leonhard Goppelt sublinha que, "partindo da teologia da palavra ou do querigma, Rudolf Bultmann devolveu à justificação um lugar central", convergindo a sua interpretação da construção teológica de Paulo para as fronteiras que encerram "o centro de sua teologia do Novo Testamento", tendo em vista que implica uma perspectiva que "entende a justificação rigorosamente no sentido forense: a justiça de Deus (genitivus objectivus) é a justiça conferida ao homem da parte de Deus, é a justiça adjudicada ao homem." (GOPPELT, 2002, p. 379) 
humano enquanto uma concordância entre a sua vontade e a lei moral em sua totalidade em um movimento que, tendo em vista o ideal da justiça ética, envolve progressão em direção ao bem (estoicismo). Além disso, se sobrepor ao sentido escatológico-forense na interpretação da justiça ("ser justificado") na construção teológico-religiosa do Apóstolo Paulo converge para uma gnose helenista e a sua concepção de justiça sob a acepção de um poder divino capaz de fluir para o interior do ser humano e produzir a expulsão dos poderes demoníacos determinantes.

Se o termo vıo $\theta \varepsilon \sigma \iota \alpha$ [filiação] encerra a singular duplicidade que caracteriza a justiça, na medida em que consiste em alvo futuro e simultaneamente envolve uma condição que se impõe ao tempo atual, no presente, conforme testificado pelo clamor $A b b a^{34}$ no dom escatológico, o paralelismo que guarda com o conceito envolvendo filiação, cujo termo jurídico-escatológico, contudo, não tem raízes no direito processual, converge para as fronteiras que implicam o sentido escatológico-existencial de justiça, tendo em vista que

assim como o alvo do evento salvífico pode ser designado pelo fato de que ele "aconteceu por causa de nossa justificação" (Rm 3.25s.; 4.25; 5.18; 2Co 5.2), também o pode finalmente

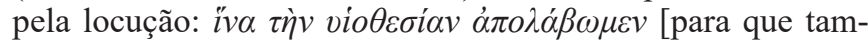
bém recebamos a filiação] (Gl 4.5). (BULTMANN, 2008b, p. 342-343)

Sobrepondo-se a uma diferenciação de caráter teórico-conceitual em relação à questão da justiça enquanto grandeza escatológico-forense, a oposição entre a construção teológico religiosa do Apóstolo Paulo e o judaísmo envolve a concepção de justiça que, se segundo a perspectiva judaica consiste em um bem da esperança, de acordo com pensamento do Apóstolo Paulo constitui uma realidade atual, guardando possibilidade de encerrar simultaneamente ambas as definições, na medida em que carrega em si tanto a presentidade quanto a futuridade em um processo que, assinalando a intersecção da futuridade entre o Apóstolo 
Paulo e o judaísmo ${ }^{35}$, tende a tornar absurda a presentidade da justiça escatológica diante do judaísmo, haja vista a impossibilidade de comprovar histórico-objetivamente os bens salvíficos, a vida escatológica e a vitória sobre o pecado e a morte senão como uma realidade subjetivo-existencial dos crentes.

\section{Aspectos Conclusivos}

Guardando correspondência com a pregação da fé em um movimento que implica uma relação que envolve em sua concreticidade o sentido de decisão enquanto ato de obediência, a fé constitui o evento escatológico em uma construção que a encerra como o novo caminho salvífico que, emergindo como a lei da fé, se contrapõe à lei das obras, consistindo em uma possibilidade que se impõe como graça e cuja realização permanece também atrelada à graça de Deus sob a acepção de uma dádiva - e isto justamente por se caracterizar como uma decisão, na medida em que "por saber que Deus é aquele que efetua seu querer e seu realizar, isto é, seu existir histórico concreto na $\pi i ́ \sigma \tau \eta$ [fé], o crente sabe que não está dispensado da responsabilidade por isso, e sim antes sabe-se remetido a ela" (BULTMANN, 2008b, p. 401) ${ }^{36}$.

Nesta perspectiva, se a fé é uma concessão de Deus em um movimento que encerra a ideia de predestinação, tal caraterização não implica, contudo, uma operação que dispense o ser humano da responsabilidade do ato de decisão, mas consiste no fato de que a referida possibilidade mantém dependência absoluta da graça de Deus e, dessa forma, constitui um evento no qual a decisão não pode emergir senão como dádiva de Deus. Tal evento escapa aos motivos intramundanos em uma construção que assinala a impossibilidade de que a fé guarde raízes em si mesma, tendo em vista que tampouco é identificada como objeto de inspiração do Espírito [ $\pi v \varepsilon v ́ \mu \alpha]$, convergindo para as fronteiras que implicam a atribuição ao Espírito do dom recebido pelo crente pela ou na fé em um processo que envolve a apropriação da graça e a sua ativação na sua vida concreta,

35. "Isso significa que Paulo adotou as expectativas escatológicas do judaísmo de sua época, mas que as transformou a partir da fé da comunidade primitiva na ressurreição de Jesus Cristo, de maneira que resultou uma simultaneidade contraditória de expectativa futura e de fé na presença da salvação escatológica." (KÜMMEL, 2003, p. 186, grifos meus)

36. Cf. Fp 2.13s. 
constituindo-se um evento escatológico a sua condição como nova criação pela ou na fé que atua no amor.

Dessa forma, sobrepondo-se ao caráter de uma doutrina da justiça que através da pregação se torna objeto de ensino, a justiça de Deus se impõe como uma possibilidade para os ouvintes da pregação em um movimento cuja realização guarda correspondência com a fé enquanto obediência e decisão, no mesmo sentido em que esta, a fé, escapa à condição de um conteúdo doutrinal que se dispõe à mediação de um processo de ensino, consistindo, como uma possibilidade que para os crentes se constitui uma realidade, uma manifestação (ou "manifestar$-s e$ ") que, sob a acepção escatológica, traz o significado de revelação (ou "ser revelado"), equivalendo a "tornar-se manifesto" 37 .

Portanto, encerrando a eliminação do passado em um processo que envolve a necessidade de manutenção da liberdade outorgada pela graça de Deus, à fé como decisão se impõe a autenticidade da auto-obrigação de renovação incessante da atitude que a implica como tal, convergindo para uma construção que traz uma renúncia baseada no ato salvífico de Deus em Cristo que emerge como uma relação com o futuro, na medida em que em sua constituição identitária a fé não apenas carrega senão que equivale propriamente à esperança, esperança enquanto esperança fundamentada na graça de Deus e que, por essa razão, torna-se confiança que, como confiança stricto sensu, é fundada no ato salvífico de Deus em Cristo.

\section{Referências}

BÍBLIA APOLOGÉTICA DE ESTUDO. Antigo e Novo Testamentos (Incluindo notas de estudo e auxílios). Tradução de João Ferreira de Almeida. Edição corrigida e revisada (Fiel ao texto original). Jundiaí/SP: ICP - Instituto Cristão de Pesquisas, 2000.

BÍBLIA DE ESTUDO DE GENEBRA. Tradução de João Ferreira de Almeida. Revista e Atualizada. São Paulo / Barueri: Cultura Cristã / Sociedade 
Bíblica do Brasil, 1999.

BROWN, Colin; COENEN, Lothar (orgs.). Dicionário internacional de teologia do Novo Testamento. Tradução de Gordon Chown. 2. ed. São Paulo: Vida Nova, 2000.

BULTMANN, Rudolf. Crer e compreender: ensaios selecionados. São Leopoldo/RS: Editora Sinodal, 2001.

BULTMANN, Rudolf. Jesus Cristo e mitologia. Tradução de Daniel Costa. 4 ed. São Paulo: Fonte Editorial, 2008a.

BULTMANN, Rudolf. Teologia do Novo Testamento. Tradução de Ilson Kayser. Santo André: Editora Academia Cristã, 2008b.

DICIONÁRIO Enciclopédico da Bíblia. São Paulo: Paulus Editora, 2014.

ESSER. H.-H. Graça. In: BROWN, Colin; COENEN, Lothar (orgs.). Dicionário internacional de teologia do Novo Testamento. Tradução de Gordon Chown. 2. ed. São Paulo: Vida Nova, 2000.

GOPPELT, Leonhard. Teologia do Novo Testamento. Tradução de Martin Dreher e Ilson Kayser. 3. ed. São Paulo: Editora Teológica, 2002.

KOESTER, Helmut. Introdução ao Novo Testamento (volume 2): história e literatura do cristianismo primitivo. Tradução de Euclides Luiz Callonii. São Paulo: Paulus, 2005.

KÜMMEL, Werner Georg. Síntese Teológica do Novo Testamento de acordo com as testemunhas principais: Jesus, Paulo, João. Tradução de Sílvio Scheider e Werner Fuchs. São Paulo: Editora Teológica, 2003.

MARIANO DA ROSA, Luiz Carlos. Abraão como protótipo de uma nova existência em Mircea Eliade e a fé como movimento envolvendo o finito e o infinito em Kierkegaard. Revista Diversidade Religiosa, UFPB Universidade Federal da Paraíba [João Pessoa, Paraíba, Brasil], v. 8, n. 1, p. 140-166, jan./jun. 2018a.

MARIANO DA ROSA, Luiz Carlos. Abraão e a espiritualidade individual como base da existência autêntica em Kierkegaard: da fé como relação $a b$ soluta com o absoluto à fé como a encarnação do absoluto no Deus-Homem Jesus Cristo. TEOLITERÁRIA - Revista de Literaturas e Teologias, PUC/SP - Pontifícia Universidade Católica de São Paulo [São Paulo, Brasil], v. 8, n. 18, p. 443-482, jun./dez. 2019.

MARIANO DA ROSA, Luiz Carlos. Abraão e a fé prototípica: da fé como paradoxo absoluto à fé como encarnação do absoluto no Deus-homem Jesus Cristo. PLURA, Revista de Estudos de Religião / Journal for the Study of Religion [ABHR - Associação Brasileira de História das Religiões], v. 9, n. 2, p. 162-184, jul./dez. 2018b. 
MARIANO DA ROSA, Luiz Carlos. Tempo da decisão e chamado à decisão na pregação ético-escatológica de Jesus Cristo: da proclamação do reino de Deus na teologia escatológico-existencial de Bultmann. Revista Último Andar, Cadernos de Pesquisa em Ciência da Religião, PUC/ SP - Pontifícia Universidade Católica de São Paulo [São Paulo, Brasil], v. 23, n. 36, p. 160-189, jul./dez. 2020 [Ensino Religioso e outras temáticas].

RIDDERBOS, Herman. A teologia do apóstolo Paulo: a obra definitiva sobre o pensamento do apóstolo dos gentios. Tradução de Suzana Klassen. São Paulo: Editora Cultura Cristã, 2004.

SCHNEIDER, J. Deus. In: BROWN, Colin; COENEN, Lothar (orgs.). Dicionário internacional de teologia do Novo Testamento. Tradução de Gordon Chown. 2. ed. São Paulo: Vida Nova, 2000.

SEEBASS, H. justiça. In: BROWN, Colin; COENEN, Lothar (orgs.). Dicionário internacional de teologia do Novo Testamento. Tradução de Gordon Chown. 2. ed. São Paulo: Vida Nova, 2000.

SJÖBERG, E; et al. Justificação. In: DICIONÁRIO Enciclopédico da Bíblia. São Paulo: Paulus Editora, 2014. 